Article

\title{
Energetic and Environmental Aspects of Individual Heat Generation for Sustainable Development at a Local Scale-A Case Study from Poland
}

\author{
Michał Kaczmarczyk *(D), Anna Sowiżdżał@ and Barbara Tomaszewska \\ Faculty of Geology, Geophysics and Environmental Protection, Department of Fossil Fuels, AGH University of \\ Science and Technology, 30-059 Kraków, Poland; ansow@agh.edu.pl (A.S.); bts@agh.edu.pl (B.T.) \\ * Correspondence: mkz@agh.edu.pl
}

Received: 18 December 2019; Accepted: 12 January 2020; Published: 17 January 2020

\begin{abstract}
The housing sector, especially with respect to energy generation to provide heating and domestic hot water, has been identified, after transport, as contributing the most to air pollution and the occurrence of low emissions in Poland. In particular, this applies to areas where there is a lack of heating and gas networks. This paper presents the results of calculations relating to the emission of atmospheric pollutants (TSP - total suspended particles as particulate matter PM10 and PM2.5, $\mathrm{SO}_{x}$ - sulphur dioxide, $\mathrm{NO}_{x}$-nitrogen dioxide, $\mathrm{CO}$ - carbon monoxide) from individual sources of heat. The fact that a commune that does not have the network infrastructure, noted above, was taken into consideration, and the structure of heat generation was estimated on the basis of coal, fuel oil and biomass. The analysis was carried out taking into account the variable heat generation structure in households depending on the fuels used, including the heating values of fuels and the efficiency of heating devices. Based on the calculations carried out, an ecological effect was obtained by assuming the replacement of heat sources by devices with higher efficiency and also by considering the possibility of using heat pumps as a zero-emission solution in the households. This article attempts to answer the question posed by municipal authorities on how to limit the negative impact on the environment of individual heating devices in order to achieve sustainable development, including the specific conditions resulting from limited infrastructural opportunities.
\end{abstract}

Keywords: sustainable development; heat generation; low emissions; earth and environmental science

\section{Introduction}

Energetic and environmental aspects of heat generation play an important role in the context of the sustainable development of each country. In the energy context, access to the energy carriers used for heat generation (heating of buildings and production of domestic hot water) and electricity production is crucial. In the ecological context, it becomes important to maximise the reduction of pollutant emissions into the atmosphere arising from the use of renewable energy sources. The consequences of energy pollution are increasingly felt in the modern world. Poland is a country that has struggled with the problem of high concentrations of pollutants in the air for many years. In the heating season, high concentrations of suspended particulate matter-PM10 (with a diameter of no more than $10 \mu \mathrm{m}$ ) and PM2.5 (with a diameter of no more than $2.5 \mu \mathrm{m}$ ) and benzo(a)pyrene (organic highly carcinogenic compound), which are highly carcinogenic compounds, $\mathrm{SO}_{\mathrm{x}}$ (sulphur dioxide-inorganic compound, a heavy, colourless, poisonous gas), $\mathrm{NO}_{\mathrm{x}}$ (nitrogen dioxide-inorganic compound, at room temperature it is a brown, highly toxic gas with a pungent odour reminiscent of chlorine gas) and $\mathrm{CO}$ (carbon monoxide-inorganic compound with strong toxic properties)—are recorded in the air. The reason for this is primarily the energy sector (based on coal), as well as transport and industrial 
emissions. Solutions currently implemented in these sectors result in the phenomenon of so-called low emissions-emissions of the products of combustion of solid, liquid and gaseous fuels into the atmosphere from emission sources (emitters) located at a height of not more than $40 \mathrm{~m}$ [1]. This issue is widely discussed at the national level [2,3] and at the global level [4-7], and the authors of the publications cited raise two main issues that should be agreed. First of all, it is widely recognised that the main reason for the problem of low emissions is the combustion of solid fuels for space heating and the production of domestic hot water. Secondly, the health, social and environmental consequences of heat generation based on conventional fuels prevent sustainable development both locally and globally. The health consequences resulting from the above-mentioned impacts are of particular importance for the functioning of society [8-12], which can mainly be overcome by changing the structure of heat generation in the municipal sector through increasing the use of renewable energy sources [13-17].

Increasing energy efficiency and reducing emissions is a key issue for many economies worldwide [18-20]. An important factor in improving air quality is increasing the use of distributed renewable energy sources, especially on a local scale [21]. A multitude of environmental, economic, political and social challenges demonstrate that current practices of natural resource management are unsustainable. Effective management of natural resources builds on political processes and governance structures [22].

The European Union (EU) strategies for a low-carbon built environment include the modernisation of heating systems in buildings by increasing the use of renewable energy sources. For example, heat pumps currently account for $5 \%$ of sales for the heating requirement and provide $3 \%$ of the energy for heating in the EU. However, in the International Energy Agency scenarios towards a sustainable future, heat pumps make up from $10 \%$ to $30 \%$ of the heating equipment stock [23].

About $79 \%$ of the energy used in EU households is for space heating and the production of domestic hot water [24]. In Poland, solid fuels, mainly hard coal (an exception at the scale of the European Union) and firewood [25], form the most important elements in the structure of energy consumption in households. The use of renewable energy is still at a very low level. In 2018, the share of energy from renewable sources in gross final energy consumption was $11.6 \%$. Over 70\% of energy obtained from renewable sources in Poland comes from biomass [26]. An increase in the importance of heat pumps has been observed in recent years, although in 2018, heat pumps were only used in one household in 200.

Responsibility for actions to improve air quality at the local scale lies with the executive bodies of local government units. Thanks to the so-called anti-smog resolutions, provincial assemblies in Poland have been given the power to introduce restrictions or a ban on the operation of installations which burn solid fuels if that prevents negative effects on human health or the environment.

This article attempts to answer the question of how to reduce the negative impact of individual heat generation on the environment in a rural area. The results obtained are to be a universal solution, and therefore the calculations were carried out for a commune typical of those located in Poland, and which does not have the infrastructure of district heating and gas networks, which, in consequence, requires the use of individual heat sources. In practice, it mainly results in the use of coal. There are 1555 rural communes in Poland, and in most of them, there is a need to exchange individual heat sources for more ecological solutions.

\section{Air Quality in Poland}

The main source of low emissions is found in the heat generation processes needed for space heating and domestic hot water $[27,28]$. This is evidenced by the data presented in Figure 1 regarding the percentage share of individual heating devices in the emissions of PM10, PM2.5 and benzo(a)pyrene. It should be emphasised that for both PM10 and PM2.5, almost 50\% of emissions are covered by so-called non-industrial combustion processes, respectively 48.5\% (PM10) and 49.7\% (PM2.5). In the case of benzo(a)pyrene, this value reaches $86 \%$, which is of particular importance. With the problem defined in this manner, it is necessary to look for solutions in the field of the modernisation of heat 
sources, especially in areas where there is no district heating or gas network infrastructure. The natural direction seems to be to increase the use of renewable energy sources, whose resources in many regions of Poland are adequate, although their level of use is still low [29-31].
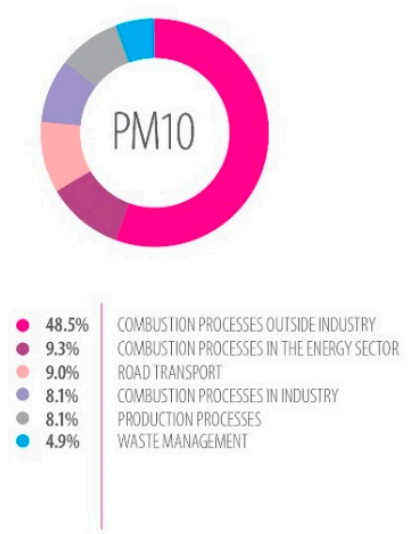
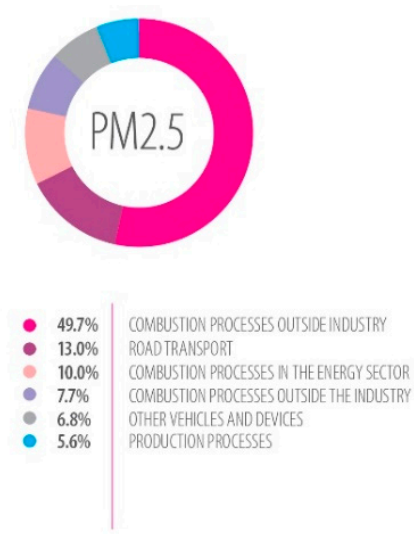
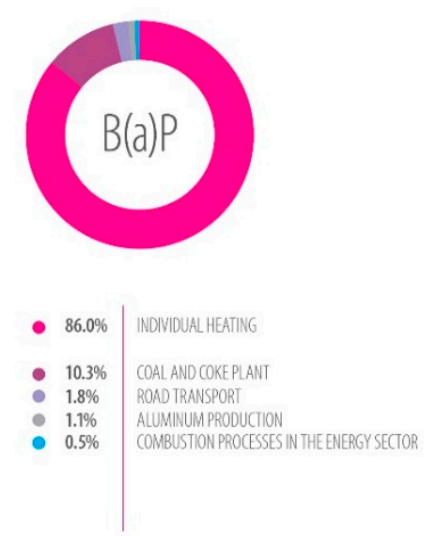

Figure 1. Sectors responsible for particulate matter (PM)10, PM2.5 and benzo(a)pyrene emissions in Poland (based on Reference [27]).

Air quality control in Poland has been carried out for several decades, and since 2004 it has been adapted to European Union regulations and requirements. The air quality monitoring system consists of various types of suitably equipped measuring stations. Research is also conducted based on other monitoring techniques, such as modelling, passive methods and additional tests [31]. Tests and assessment of air quality in Poland, in accordance with the Act on Environmental Protection [32], are carried out by the Inspectorates of Environmental Protection as part of the State Environmental Monitoring (SEM) system. The average annual norms for individual pollutants are, respectively: for PM10 $-40 \mu \mathrm{g} / \mathrm{m}^{3}$, for PM2.5-25 $\mu \mathrm{g} / \mathrm{m}^{3}$, for benzo(a)pyrene $-1 \mathrm{ng} / \mathrm{m}^{3}$, for $\mathrm{SO}_{2}$ and $\mathrm{NO}_{\mathrm{x}}-20 \mu \mathrm{g} / \mathrm{m}^{3}$ (applicable acceptable levels for plant protection), for $\mathrm{NO}_{2}-40 \mu \mathrm{g} / \mathrm{m}^{3}$ and for $\mathrm{CO}-10,000 \mu \mathrm{g} / \mathrm{m}^{3}$ (concentration averaging period, $8 \mathrm{~h}$ ).

The results of the annual air quality assessment for 2017 in Poland do not significantly differ from the results obtained in 2016 and in previous years. There is a slight increase (compared to 2016) in the number of exceedances set for PM2.5 and PM10 for the criterion on average annual concentrations and an improvement of these parameters compared to 2015. For benzo(a)pyrene, the highest average annual values were obtained as a result of measurements carried out in 2017 in the following provinces: Małopolska $\left(22.7,14.6\right.$ and $\left.10.0 \mathrm{ng} / \mathrm{m}^{3}\right)$, Silesia $\left(16.0,14.5\right.$ and $\left.12.3 \mathrm{ng} / \mathrm{m}^{3}\right)$ and Lower Silesia $\left(15.9 \mathrm{ng} / \mathrm{m}^{3}\right)$. In the case of PM10 dust, the highest average annual concentration in 2017 was recorded at urban background stations in the Małopolska $\left(64.3 \mu \mathrm{g} / \mathrm{m}^{3}\right)$ and Silesia $\left(55.6 \mu \mathrm{g} / \mathrm{m}^{3}\right)$ zones. In previous years, the value of this parameter was the highest at the communication station in the Kraków Agglomeration $\left(56.7 \mu \mathrm{g} / \mathrm{m}^{3}\right.$ in 2016 and $67.8 \mu \mathrm{g} / \mathrm{m}^{3}$ in 2015) [27].

These data prove that the air quality standards in Poland are permanently exceeded. This is also demonstrated in data published by the European Environment Agency [28]. The problem of exceeding the permissible standards applies mainly to PM10, PM2.5 and benzo(a)pyrene, and to a lesser extent $\mathrm{SO}_{x}, \mathrm{NO}_{x}$ and CO. Figures 2 and 3 show data on the concentration of PM10 and PM2.5 in 2016 (annual limit value) in Europe [28], where Poland is characterised by one of the highest exceedances of permissible PM10 standards (locally above $50 \mu \mathrm{g} / \mathrm{m}^{3}$ ) and PM2.5 (locally exceeding $30 \mu \mathrm{g} / \mathrm{m}^{3}$ ). 


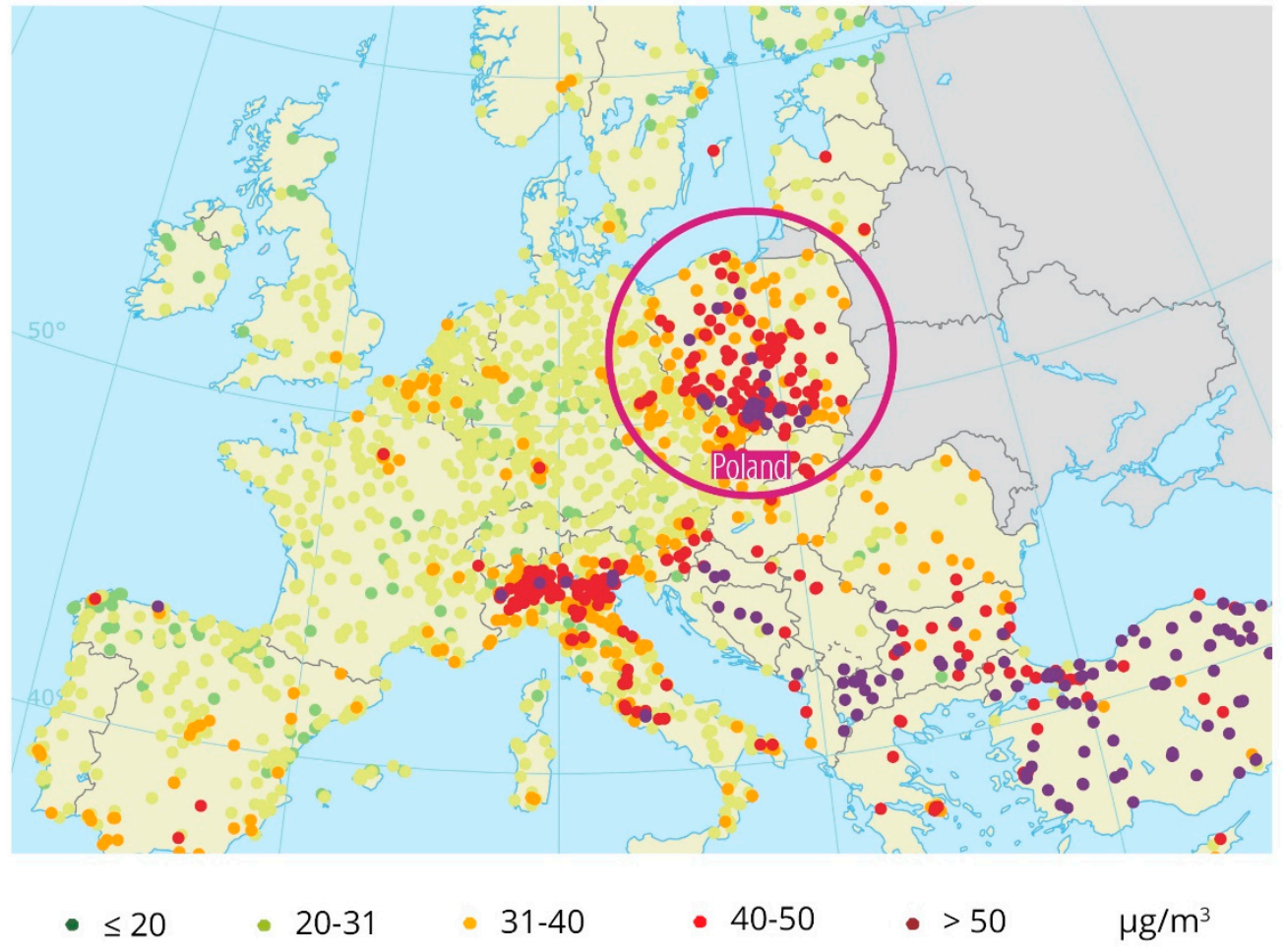

Figure 2. Concentration of PM10 in Poland and Europe in 2016 (based on Reference [28]).

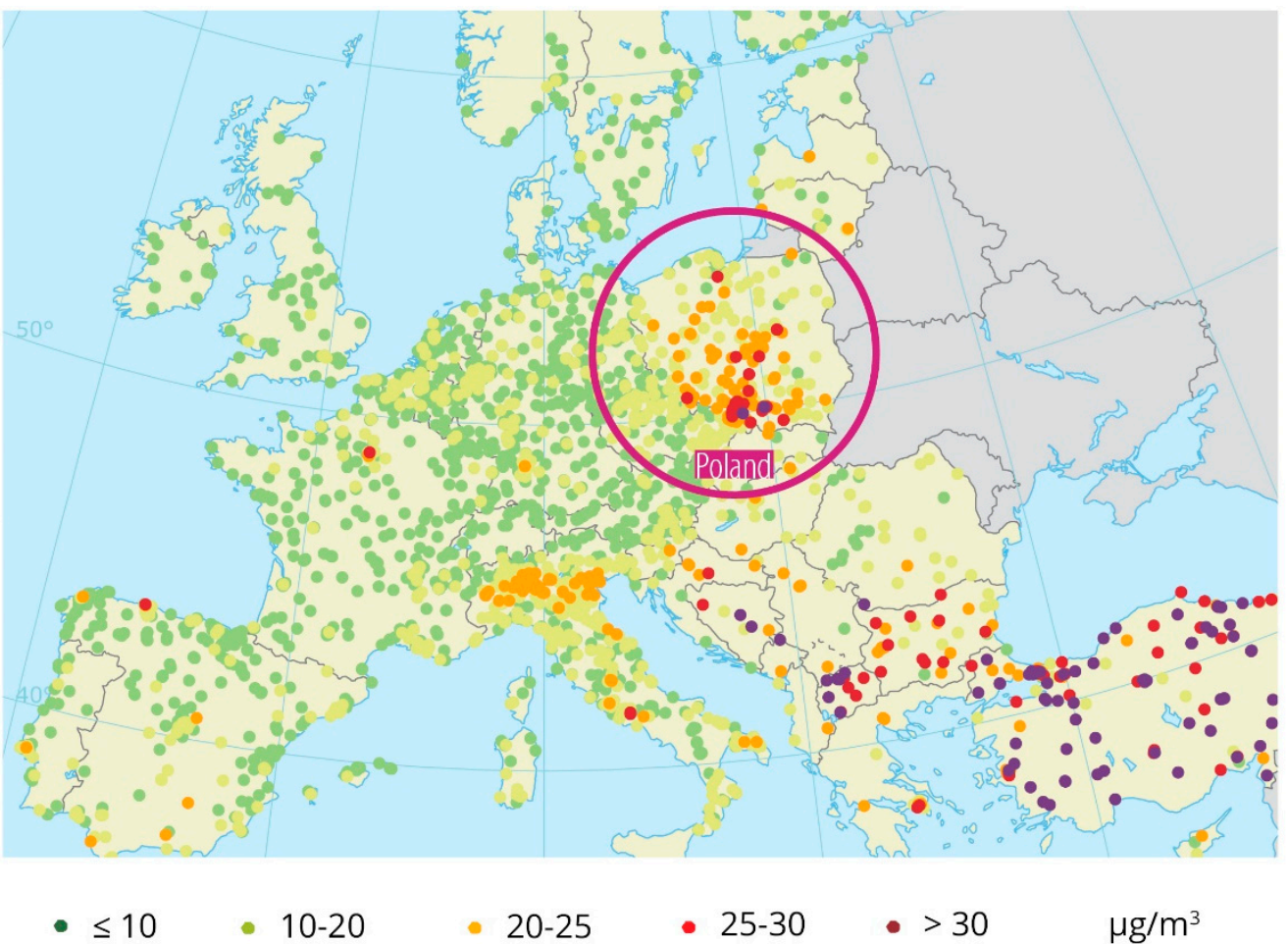

Figure 3. Concentration of PM2.5 in Poland and Europe in 2016 (based on Reference [28]).

Access to the infrastructure of heating and gas networks is also a problem. Statistical data on the population using gas from the network and gas consumption per capita indicate that $52.1 \%$ of the population used gas in Poland in 2017 (Figure 4). This value should be considered as low. In addition, taking into account the fact that it was $71.2 \%$ in urban areas and only $23.3 \%$ in rural areas, there is an obvious conclusion of a link to limited access to the gas network [25]. The lack of local heating networks 
was recognised as the second element excluding municipalities from the possibility of sustainable development and improvement in air quality. Statistical data on the density of heating networks in 2017 in Poland indicate an average length of $8.1 \mathrm{~km}$ per $100 \mathrm{~km}^{2}$. The most important issue, however, is that $98.3 \%$ of the heating networks occur in urban areas (Figure 5). Unfortunately, the fuel used in existing heating plants is usually solid fuel, at $66.2 \%$ [25].
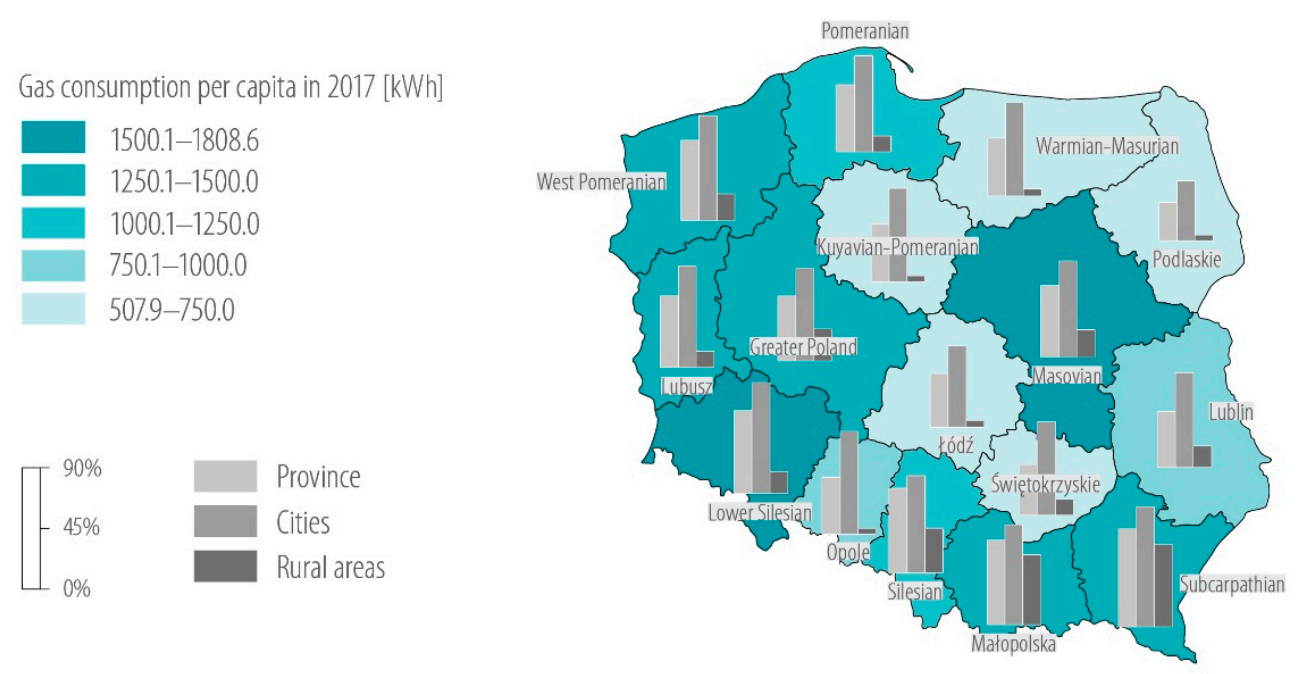

Figure 4. Population using gas from the network and gas consumption per capita in 2017 (based on Reference [25]).

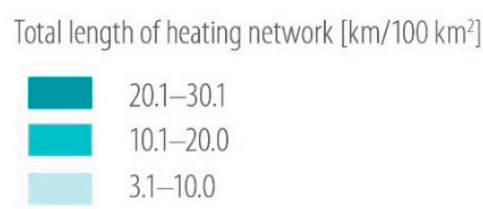

Average for Poland -8.1

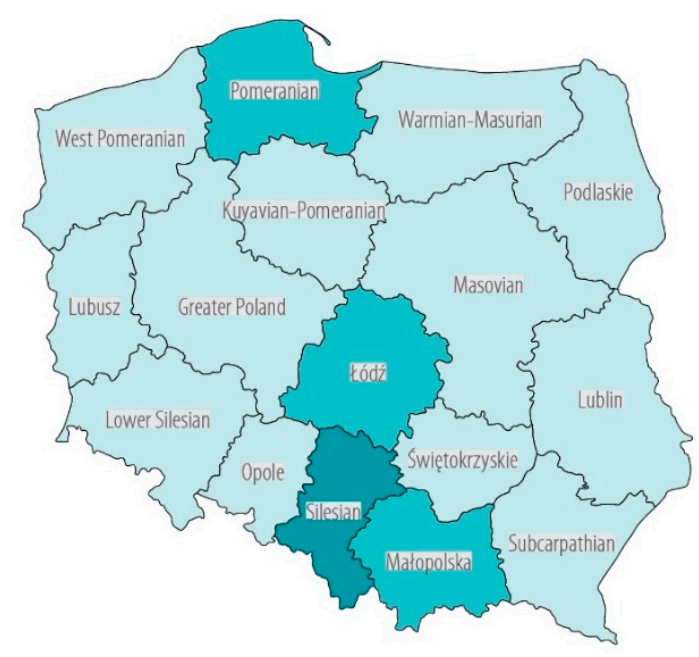

Figure 5. Heat network density in 2017 (based on Reference [25]).

There are 1555 rural communes in Poland, which in relation to the above data shows the scale of the problem. Lack of access to the network infrastructure necessitates the use of other energy carriers. Additionally, statistical data published by the Central Office of Building Control [33] indicate that the number of building permits issued in Poland in 2018 was 196,322 (226,469 facilities) and these should be taken into account. In this overall figure, residential buildings accounted for 98,915 , of which, $94.7 \%$ were single-family houses. Unfortunately, $65 \%$ of newly built houses are equipped with solid fuel boilers [34]. The above statement is confirmed by data on fuels used to generate energy for space heating and domestic hot water purposes, as presented in Figure 6. 


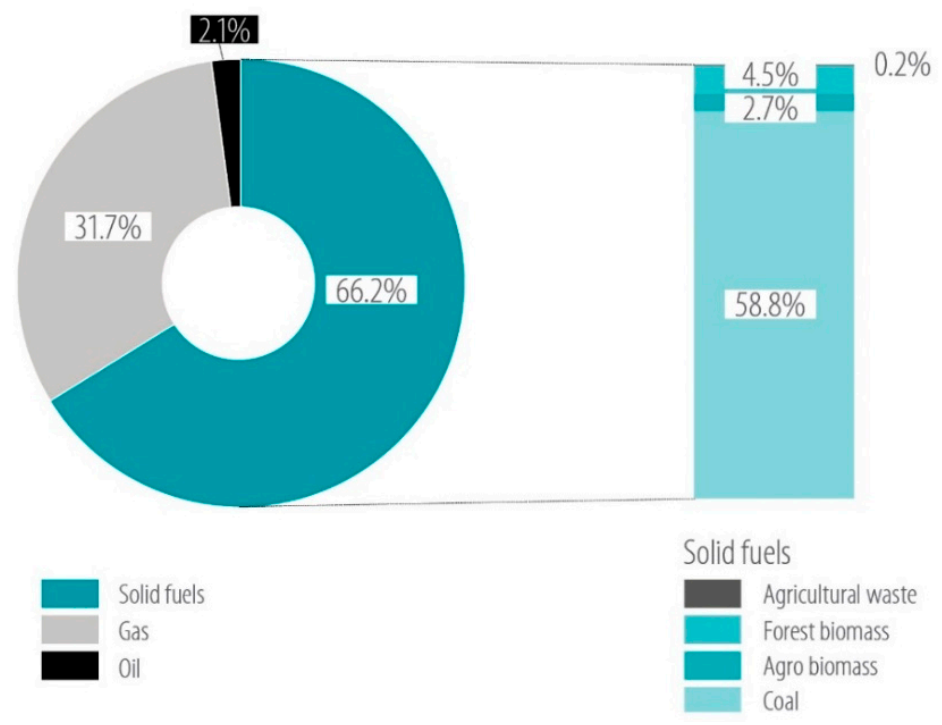

Figure 6. Types of fuels used to generate heat for heating purposes in 2017 (based on Reference [25]).

\section{Materials and Methods}

Analytical work was carried out for a theoretical rural commune with a population of 8000 . Taking into account the statistical data [35,36], the density of population in rural communes in Poland is from 100 to 149 people per square kilometre (78.4\% of all rural communes.) In addition, the average area of a rural commune in Poland is $126 \mathrm{~km}^{2}$. Multiplying these values gives a range of $12,600-18,774$ inhabitants. Considering the data on access to the gas network in Poland $(52.1 \%)$ and assuming an uneven distribution of the size of municipalities in terms of population, it was decided to adopt the value of 8000 inhabitants as representative.

The average number of people in a household was adopted as 3.4 [25], which allowed us to calculate the total number of households in the commune as being 2353. According to data published by the Central Statistical Office [25], the average area of a household in Poland in a rural region is $108.3 \mathrm{~m}^{2}$. The average energy demand is $216 \mathrm{kWh} / \mathrm{m}^{2}$ year [37]. This information allowed for the calculation of the total heat demand of a commune for space heating and domestic hot water production, at $198,150.776$ GJ. The first stage was to determine the structure of the energy carriers and heating devices used. As a baseline, it was assumed that $70 \%$ of the inhabitants of the commune use coal to produce heat, $25 \%$ use biomass and $5 \%$ use fuel oil (Model 1). Simulations of the potential ecological effect resulting from the exchange of the energy source were carried out in six variants (Model 2-7), assuming different shares of energy carriers in the energy balance of the commune.

The analysis was carried out for six models:

- Model 2 (biomass dominance): $70 \%$ biomass, $25 \%$ coal, $5 \%$ fuel oil.

- Model 3 (balanced): $47.5 \%$ coal, $47.5 \%$ biomass, $5 \%$ fuel oil.

- Model 4 (balanced with increased efficiency): $47.5 \%$ coal, $47.5 \%$ biomass, $5 \%$ fuel oil, $5 \%$ increase in nominal heating device efficiency.

- Model 5 (share of heat pumps): $40 \%$ coal, $40 \%$ biomass, $5 \%$ fuel oil, $15 \%$ heat pump.

- Model 6 (share of heat pumps and increase in efficiency): $40 \%$ coal, $40 \%$ biomass, $5 \%$ fuel oil, $15 \%$ heat pump, $5 \%$ increase in nominal efficiency of heating devices.

- Model 7 (100\% from renewable energy): $50 \%$ biomass, $50 \%$ heat pump.

Model 2 is included in the models calculated above due to a desire to compare the base state pollutant emissions with other models, assuming that renewable energy provision is predominantly provided by solid fuel boilers fired with biomass. The assumptions for models $4-6$ result from the technical and financial possibilities of a total departure from solid fuels towards renewable energy 
sources, hence a balanced share of solid fuel boilers fired with coal and biomass was assumed, with a constant share of fuel oil, however with the assumption of an increase in the share of heat pumps, as well as an increase in the nominal efficiency of heating devices resulting from the modernisation of the heat source. Model 7, based on the use of biomass and heat pumps, was adopted as the most ecological solution because of the need to strive to increase the share of renewable energy sources when generating heat for space heating and domestic hot water.

Each of the energy carriers analysed was assigned lower heating values (LHW) and the nominal efficiency of heating devices (in the case of oil boilers, including traditional and condensing boilers) on the basis of the catalogues of heating equipment manufacturers and the typical lower heating values (LHW) of conventional fuels and the efficiency factor of the heat pump in Polish conditions (Table 1) [38]. In total, six types of biomass were analysed (pellets, dry wood, straw briquettes, wood briquettes, rape straw, corn straw), three types of coal (eco-pea coal, nut coriander, culm), two types of fuel oil (light and heavy) and three types of heat pumps (air/water, brine/water with vertical heat exchanger, brine/water with horizontal heat exchanger).

Table 1. Type of fuels, nominal efficiency and lower heating value (LHW) used in calculations [38].

\begin{tabular}{cccc}
\hline \multirow{2}{*}{ Type of Fuel } & $\begin{array}{c}\text { Nominal } \\
\text { Efficiency (-) }\end{array}$ & $\begin{array}{c}\text { Lower Heating Value } \\
\text { (LHW) (MJ/Unit) }\end{array}$ \\
\hline \multirow{3}{*}{ Biomass } & Pellet & $0.80-0.88$ & $17.0-21.0$ \\
& Dry wood & $0.80-0.88$ & $16.0-19.0$ \\
& Straw briquette & $0.80-0.88$ & $16.9-17.1$ \\
& Wood briquette & $0.80-0.88$ & $16.1-20.4$ \\
Rape straw & 0.80 & 15.0 \\
\multirow{2}{*}{ Coal } & Corn straw & 0.80 & 16.8 \\
\hline \multirow{2}{*}{ Coke } & Ekogroszek & 0.75 & $24.0-28.0$ \\
\multirow{2}{*}{ Light fuel oil } & Nut-type coal & 0.75 & $24.0-28.0$ \\
& Culm & 0.75 & $18.0-26.0$ \\
\hline \multirow{2}{*}{ Heavy fuel oil } & Coke & 0.75 & 27.0 \\
& Condensing boiler & 0.99 & 36.12 \\
& Traditional boiler & 0.88 & 36.12 \\
\hline \multirow{2}{*}{ Heat pump } & Condensing boiler & 0.99 & 39.7 \\
& Traditional boiler & 0.88 & 39.7 \\
\hline & Brine/water with horizontal heat exchanger & $3.5-4.0$ & 3.6 \\
& Air/water & 3.5 & 3.6 \\
\hline
\end{tabular}

In the case of heat pumps, it was decided to consider three variants because of their widespread use in Polish conditions. The temperature stability of the ground as a heat source is important from the point of view of using a heat pump for heating and domestic hot water preparation, hence it was decided to consider devices with vertical and horizontal heat exchangers. However, taking into account the changing standards for new buildings (decreasing demand for heat), an air/water heat pump for central heating and domestic hot water preparation has also been taken into account. This type of device is increasingly used due to the investment costs, which are lower because of the lack of the need to carry out work related to the implementation of the heat source.

Arithmetic means were calculated for individual groups (biomass, coal, fuel oil and heat pumps) and then the percentage share of the model analysed was assigned.

In addition, an increase in nominal efficiency has been assumed for solid-fuel boilers (coal and biomass). For biomass boilers, the efficiency increase was assumed to be from $80 \%-88 \%$ to $90 \%$, while for coal boilers from $75 \%$ to $80 \%$. The emission of pollutants into the atmosphere was calculated on the basis of the National Centre for Emissions Management (KOBIZE) guidelines, on emission factors for 
fuel combustion in boilers with a nominal thermal capacity of $5 \mathrm{MW}$ [39]. Calculations were made according to the equations:

$$
B=\frac{Q \cdot A}{\eta \cdot W_{O}}
$$

where:

$B$-amount of fuel $\left(\mathrm{m}^{3}\right)$ or $(\mathrm{Mg})$,

$Q$-amount of energy produced (MJ $/ \mathrm{m}^{2}$ rok), assuming $1 \mathrm{MJ} / \mathrm{m}^{2}$ year,

$A$-heated area $\left(\mathrm{m}^{2}\right)$, assumed $1 \mathrm{~m}^{2}$,

$\eta$-boiler efficiency $(-)$,

$\mathrm{W}_{O}$-lower heating value $(\mathrm{LHW})$ of fuel, $\left(\mathrm{MJ} / \mathrm{m}^{3}\right)$ or $(\mathrm{MJ} / \mathrm{Mg})$.

$$
E=B \cdot W
$$

where:

E—emission of pollutants (g/MJ),

$B$-amount of fuel, $\left(\mathrm{m}^{3}\right)$ or $(\mathrm{Mg})$,

$\mathrm{W}$-emission factor $(\mathrm{Mg})$.

\section{Results}

The results of the calculations are shown in Figures 7-13. Model 1, with a 70\% share of coal, a 25\% share of biomass and a 5\% share of fuel oil, was adopted as the baseline, against which further variants of the calculations were compared. The results obtained (Figure 7) showed the quantities of pollutants emitted into the atmosphere during the year to be: $\mathrm{SO}_{x}-35,191 \mathrm{~kg}, \mathrm{NO}_{\mathrm{x}}-11,394 \mathrm{~kg}, \mathrm{CO}-234,280 \mathrm{~kg}$ and TSP (particulate matter PM10 and PM2.5)—55,639 kg.

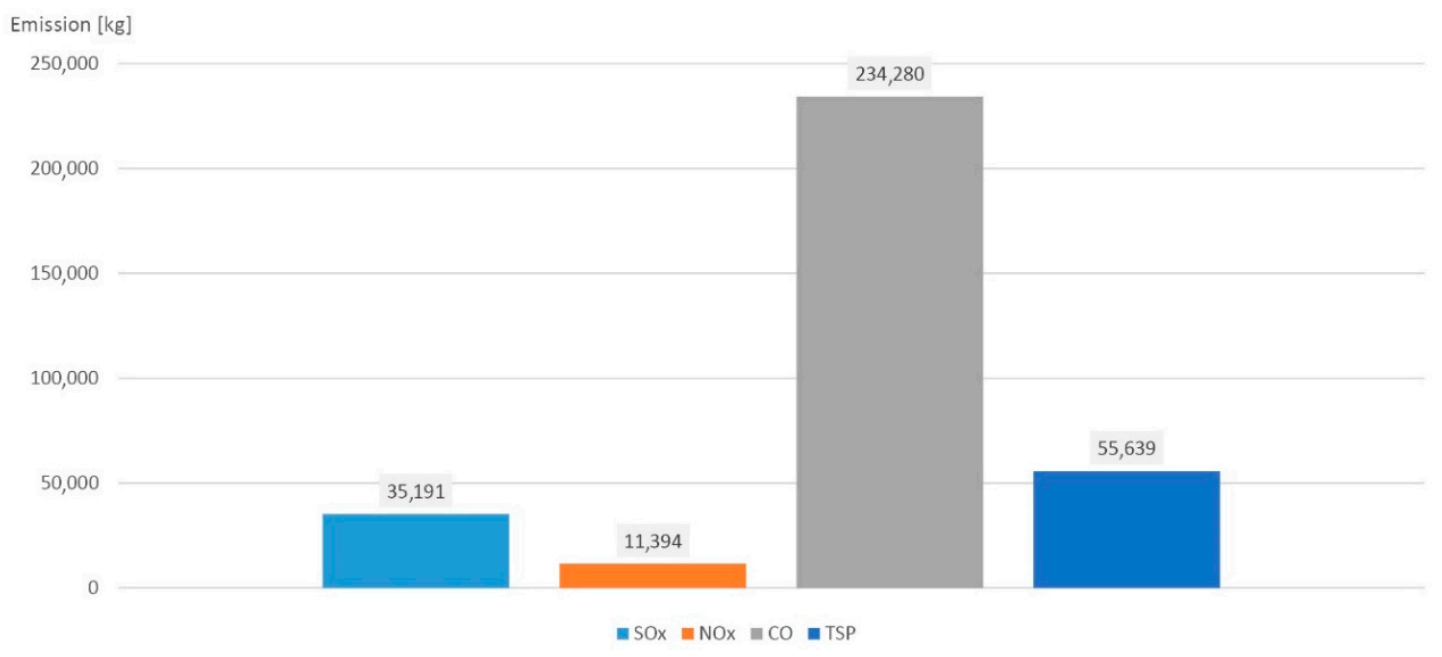

Figure 7. Annual emissions of pollutants in the baseline scenario (Model 1): 70\% coal, 25\% biomass, $5 \%$ fuel oil.

The results obtained in Model 2 (Figure 8), assuming the opposite situation in relation to the base state $-70 \%$ share of biomass, $25 \%$ share of coal and $5 \%$ share of fuel oil—indicate a significant reduction in emissions, depending on the pollutant concerned, ranging from $11.23 \%$ to $59.45 \%$. By far the largest emissions reduction concerns $\mathrm{SO}_{\mathrm{x}}(59.45 \%)$ and $\mathrm{TSP}(24.23 \%)$. The smallest reduction is CO, at $11.23 \%$. In Model 3 (Figure 9), an equal share of coal and biomass utilisation was assumed at $47.5 \%$, with a $5 \%$ share of fuel oil. The results obtained indicate about half of the reductions seen in the case of Model 2, that is, in the range $5.62 \%-29.72 \%$. 


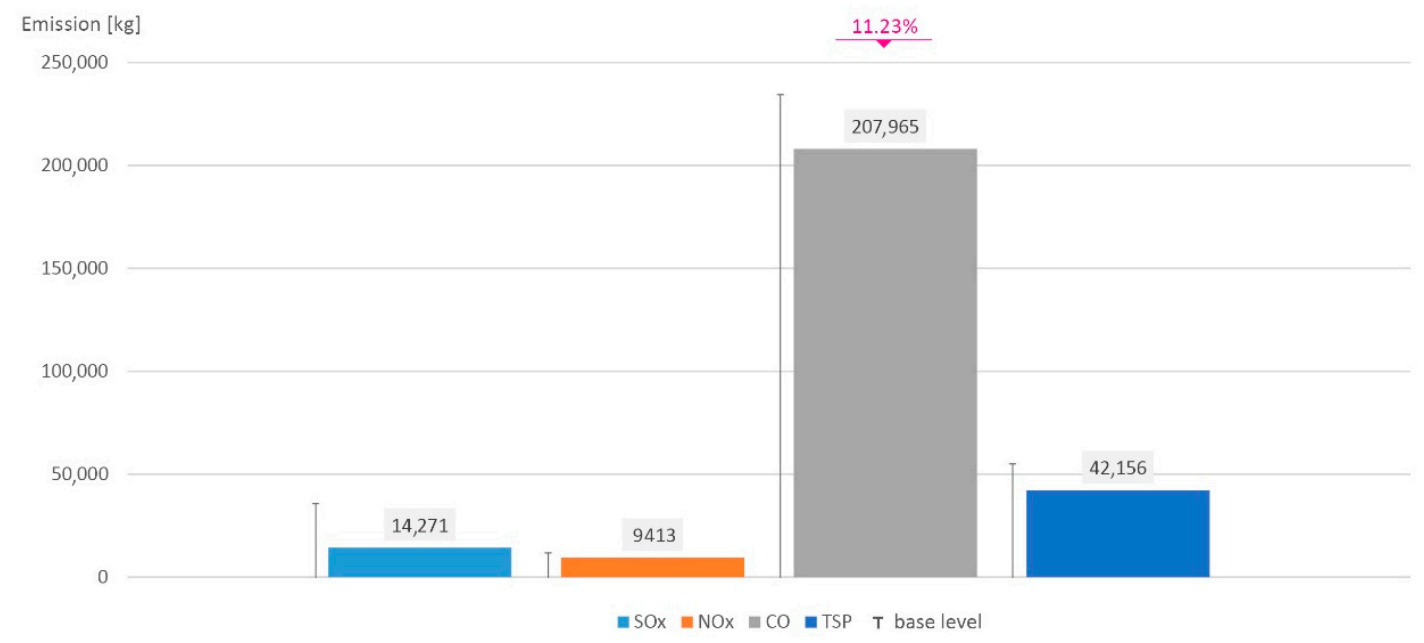

Figure 8. Annual emissions of pollutants in Model 2: 25\% coal, 70\% biomass, $5 \%$ fuel oil.

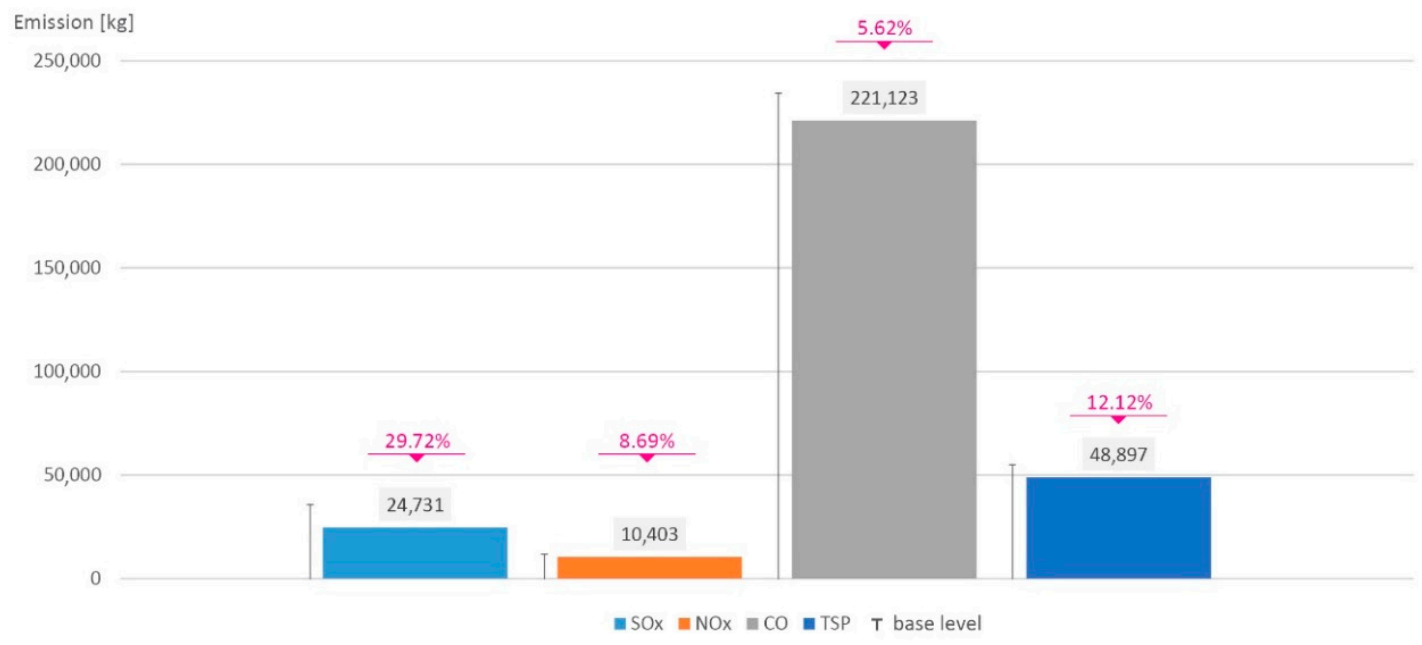

Figure 9. Annual emissions of pollutants in Model 3: 47.5\% coal, 47.5\% biomass, $5 \%$ fuel oil.

The last model, which does not take into account the share of heat pumps using renewable energy sources, was Model 4 (Figure 10), based on the same assumptions as Model 3, but with the additional condition that the efficiency of heating devices would increase by $5 \%$. The assumed value of the increase in efficiency is relatively low, but this is because the increase in the efficiency of the entire space heating and domestic hot water installation (transmission, regulation and accumulation efficiency) is taken into account, and not just the efficiency of heat generation. Nevertheless, the results obtained show that the replacement of solid fuel boilers with class- 5 boilers that meet the requirements of EcoDesign, even without a comprehensive modernisation of the installation, brings the desired results. Compared to Model 4, the reduction in $\mathrm{SO}_{x}$ increased from $29.72 \%$ to $33.80 \%$, for $\mathrm{NO}_{\mathrm{x}}$ from $8.69 \%$ to $14.19 \%$, for CO from $5.62 \%$ to $11.87 \%$ and for TSP from $12.12 \%$ to $18.71 \%$. It is worth noting that in the case of the reduction of CO emissions, the value of $11.87 \%$ obtained in Model 3 is slightly higher than in the case of Model 1, where it was $11.23 \%$. 


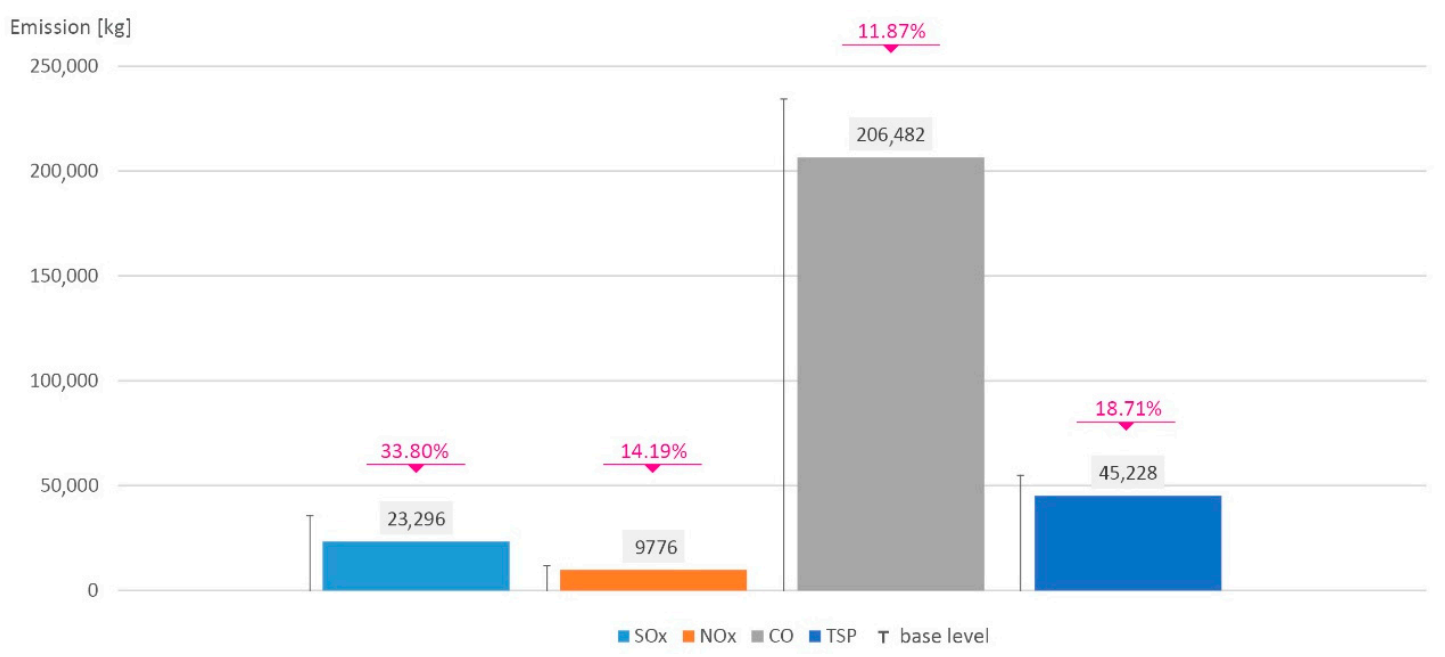

Figure 10. Annual emission of pollutants in Model 4: $47.5 \%$ coal, $47.5 \%$ biomass, $5 \%$ fuel oil and $5 \%$ improvement in the efficiency of the devices.

Models 5 and 6 contain a 15\% share of heat pumps. This is an optimistic and cautious option, which results from the development of the heat pump market in Poland and the decreasing price difference between class- 5 solid fuel boilers and air/water heat pumps. On the other hand, it is difficult to foresee a heat pump in buildings with high heat demand and possessing a heating system operating at high supply temperatures. This is due to the need to modernise the installation to work at the lower temperatures required by heat pumps for efficient operation. The results of the calculations for models 5 (Figure 11) and 6 (Figure 12) show a higher level of pollution reduction for $\mathrm{NO}_{\mathrm{x}}, \mathrm{CO}$ and TSP than in all the other models investigated. Only in the case of $\mathrm{SO}_{\mathrm{x}}$ are the values better than those in Model 2. Emissions of pollutants are reduced by: $39.99 \%-43.43 \%$ for $\mathrm{SO}_{\mathrm{x}}, 21.88 \%-26.5 \%$ for $\mathrm{NO}_{\mathrm{x}}$, $20.51 \%-25.77 \%$ for CO and $25.93 \%-31.49 \%$ for TSP.

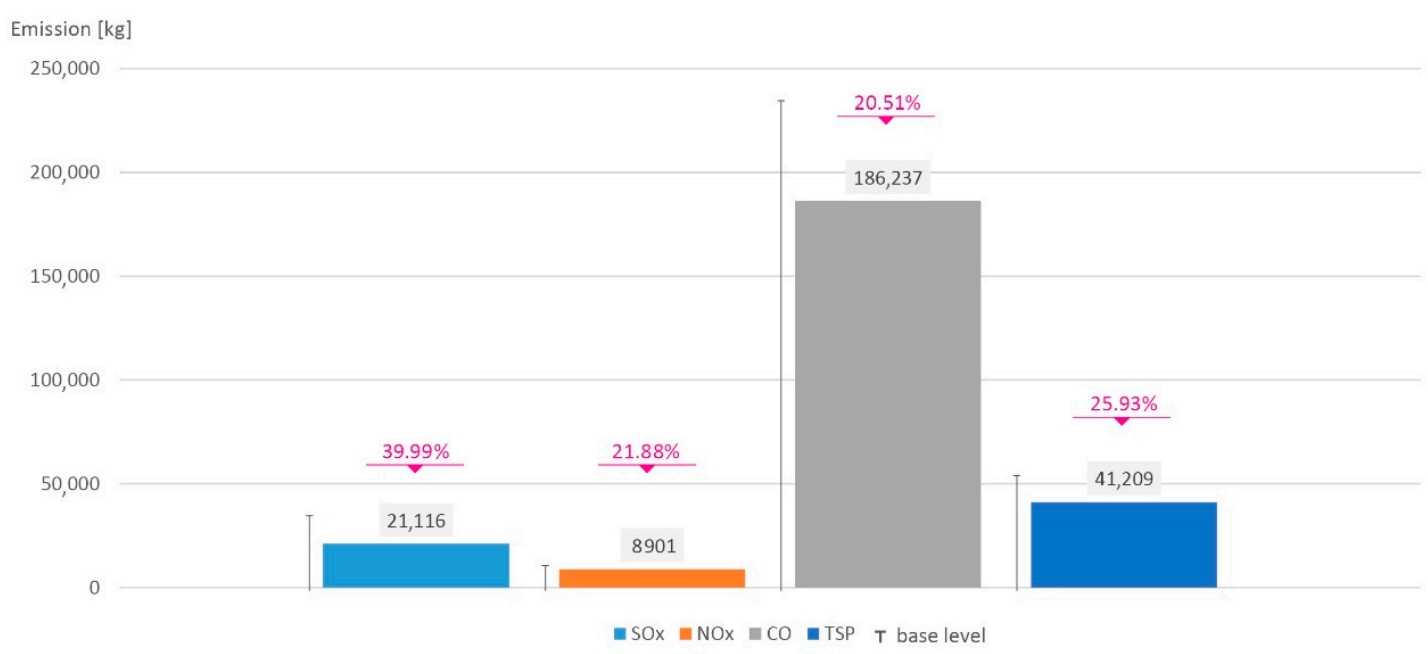

Figure 11. Annual emissions of pollutants in Model 5: 40\% coal, 40\% biomass, 5\% fuel oil, 15\% heat pumps. 


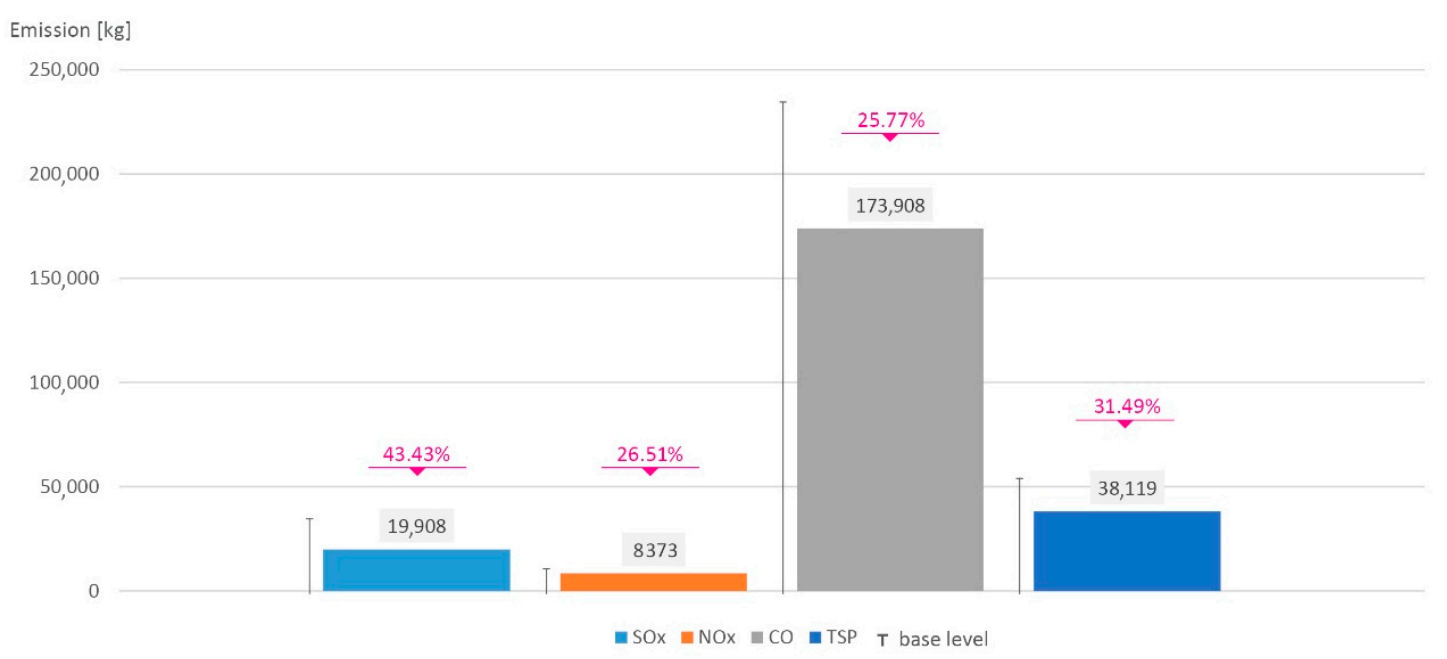

Figure 12. Annual emissions of pollutants in Model 6: 40\% coal, $40 \%$ biomass, $5 \%$ fuel oil, $15 \%$ heat pumps and $5 \%$ growth of the efficiency of devices.

The conclusions drawn from the analysis of the results obtained in models 2-6 indicate that the optimal solution would be the replacement of coal-fired solid-fuel boilers with solutions based on the use of renewable energy sources. For this reason, a model in which only biomass boilers and heat pumps are used (each technology providing 50\%), was also investigated. When compared to the baseline, Model 7, to which these assumptions refer, indicates the highest reduction of pollutant emissions to the atmosphere, as shown in Figure 13. In the case of $\mathrm{SO}_{\mathrm{x}}$, it is a reduction of $403 \mathrm{~kg}$, which is $87.32 \%$ less than in the base state. For $\mathrm{NO}_{\mathrm{x}}$, it is $3636 \mathrm{~kg}(68.09 \%)$, for CO, 94,439 $\mathrm{kg}(59.69 \%)$ and for suspended dust TSP, $16,344 \mathrm{~kg}(70.63 \%)$.

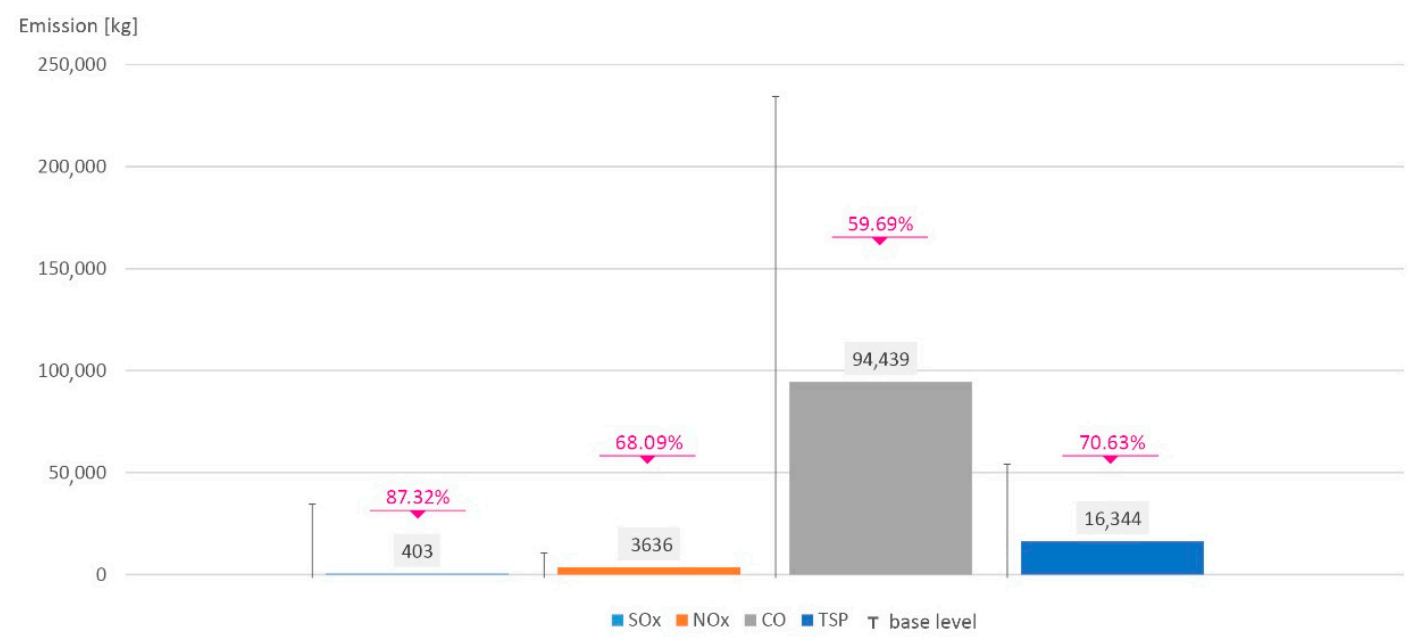

Figure 13. Annual emissions of pollutants in Model 7: 50\% biomass, 50\% heat pumps.

In addition, the possibilities of achieving the proposed changes over a 10-year period were also analysed. The calculation was based on the above models, where the baseline was dominated by coal in addition to models which make use of heat pumps and the increase in efficiency of solid-fuel boilers (Figure 14), as well as a model which only uses renewable energy sources-biomass boilers and heat pumps (Figure 15). The analysis was conducted for the period 2019-2029. The values for individual years were calculated based on the assumption of a regular change in the proportions in the structure of devices and fuels used. The difference in the percentage of the baseline and target state was divided by the value of ten years, which for each group of devices and fuels gave an annual change. The results obtained clearly show that moving away from hard coal combustion to renewable energy sources results in a significantly faster means of achieving reduced emissions and achieving the 
target thresholds. This is evidenced by achieving better values than the target threshold from Model 6 for the variant with $100 \%$ share of renewable energy sources in 2024 , i.e., five years earlier.

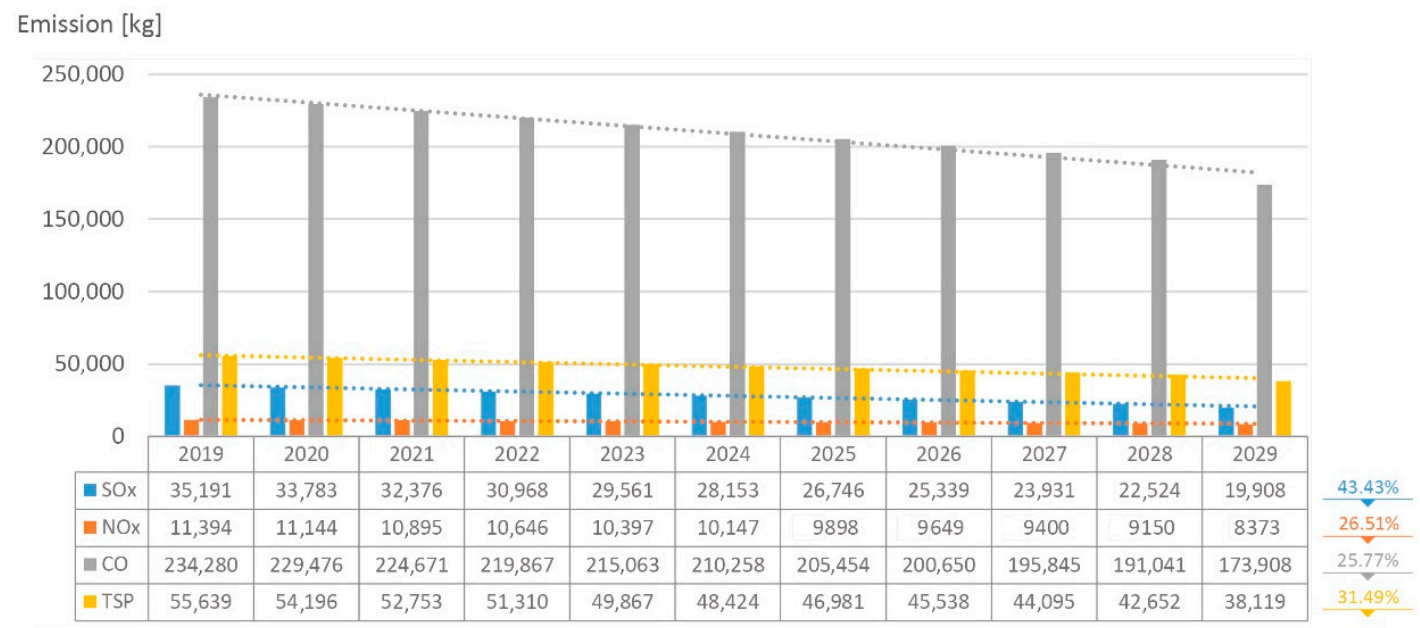

Figure 14. Change in pollutant emissions to the environment in the period 2019-2029, including the change in efficiency resulting from the implementation of Model 6.

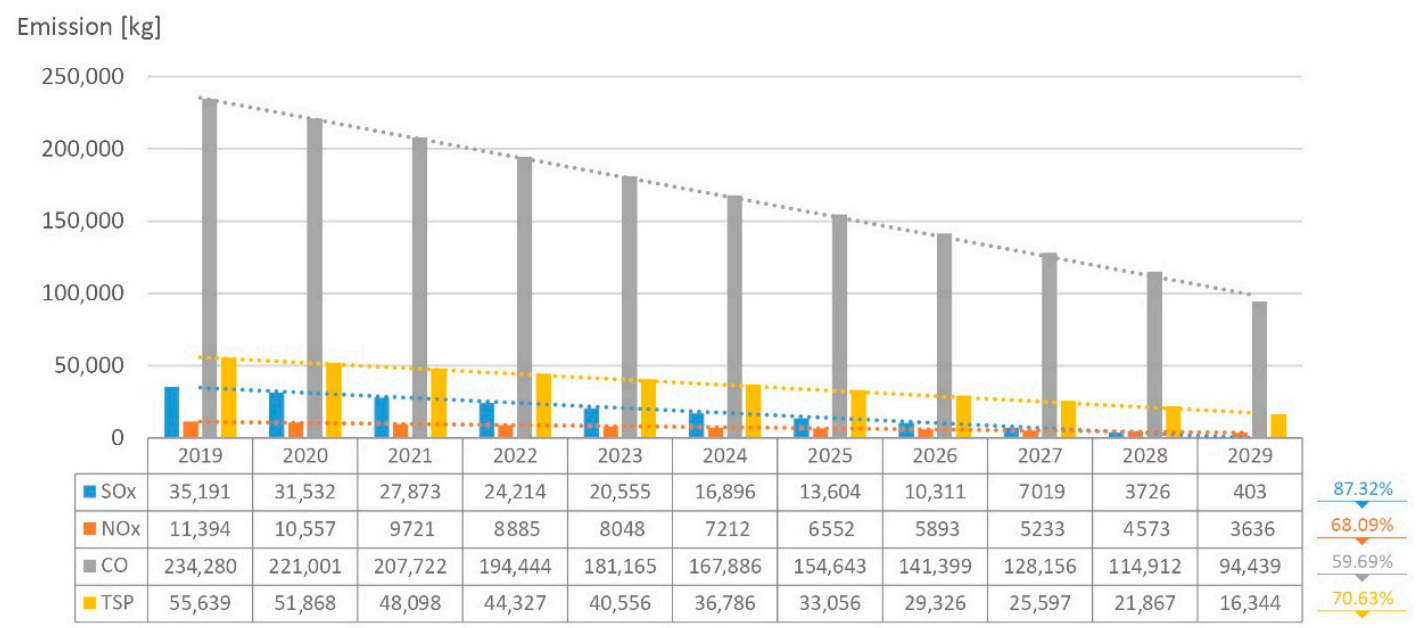

Figure 15. Change in pollutant emissions to the environment in the period 2019-2029, including the change in efficiency resulting from the implementation of Model 7.

\section{Discussion}

In the context of the results obtained, it is important to plan specific actions to improve the quality of the environment and increase energy efficiency in the region. In the context of energy planning, the methodology presented in this article and the results obtained can certainly complement activities at the regional level. This is particularly important in order to understand the potential of renewable energy sources to improve the quality of the environment, primarily by using heat pumps as a zero-emission technology in the households. The results obtained during the research clearly indicate that the optimal model of those proposed is the one based on the use of biomass and heat pump technology. By analysing the dynamics of change, it can be seen that the rate of reduction of pollutant emissions, when compared to the other models, is at least twice as high.

However, it should be noted that the barrier to achieving the assumed goals may be social acceptance of the proposed solutions resulting from, among other influences, the wealth of society. In a similar context, namely the essence of social acceptance of renewable energy, Schumacher, Krones, McKenna and Schultmann [40] made the following comments. They note that this is largely dependent on a given technology and the researcher's overall experience in renewable energy, as well as the level 
of experience in the field of energy autonomy. The last of the terms, i.e., energy autonomy, may be important in the future because the interesting vision is the role of rural areas as renewable energy exporters to cities in order to meet their growing energy demand [41].

Although the purpose of this study was to address individual heat sources and focus on the thermal management of buildings, it is worth bearing in mind that in an energy planning situation, decision makers should be aware of the potential consequences for public acceptance when setting framework conditions to support specific technologies or projects. In addition, one should agree with the statement [40] that opinion polls at the national level cannot be used as a basis for decisions for local projects in the field of renewable energy sources and sustainable development, because the subject of acceptance is simply different and the approval for specific projects associated with renewable energy sources must be assessed on a case-by-case basis.

Returning to the results obtained during the research, the need to decarbonise energy systems in both rural and urban areas is unambiguous. Kostevsek, Petek, Cucek, Kleme and Varbanov [42], as well as Benedek, Tihamér-Tibor and Bartók [43], agree that one of the most important issues relating to the current energy policy is the need to focus on local energy systems and the role of renewable energy in these systems. In the context of this article, it should be stated that this is the right approach, and therefore one should strive to do this, mainly in rural areas characterised by a lack of district heating systems or access to natural gas as a more ecological energy carrier than hard coal or heating oil. An additional advantage of this approach to energy systems, among other approaches proposed in rural areas, is that it is possible to use them as a tool to improve energy security and support economic development [43].

The calculations carried out showed large ecological benefits resulting from the use of renewable energy sources, although the use of only renewable sources in households in the coming years seems unrealistic in Poland. Systems based on renewable energy sources such as sun or wind, which are characterised by unpredictability, require the use of peak sources (e.g., gas or electric) or adequate energy storage technologies; therefore, real energy models are those that take into account both renewable and conventional sources.

It should be added that the production of energy from renewable sources is likely to be more decentralised in the future, which may lead to potentially significant changes in the regional economy. Undoubtedly, one should agree with the statement that in the context of the region and its energy transformation, reference should be made to such aspects as employment rates, supply chain analyses, input-output models or economic losses in conventional energy generation sectors due to the growing share of energy production from sources of renewable energy in the structure of local energy production [44]. Renewable energy systems are becoming a strong element of local sustainable development strategies. The answer to the question remains whether direct financial support for renewable energy systems has an impact on the increase in the use of renewable energy [45]. It seems that in Polish conditions, with a less prosperous society and a not very well-developed renewable energy sector, direct support may, however, be the main incentive to invest in renewable energy.

\section{Conclusions}

The occurrence of low-level emissions in Poland is a common phenomenon, which is confirmed annually by reports of the Chief Inspectorate for Environmental Protection in Poland and the European Environment Agency. The main reason for this is the individual combustion of solid fuels to provide space heating and domestic hot water. In the case of rural communes, the reasons for such a situation should be seen, first of all, in the lack of a heating and gas network infrastructure, and secondly, in the wealth of society. The calculation results presented in this article clearly showed that the current structure of heat generation based on fossil fuels is unfavourable from the point of view of environmental protection.

One cannot indicate one utilitarian model of conduct for each rural commune in Poland, because each of them has different geographical, topographic, spatial and economic conditions. However, it is 
possible to analyse the situation in municipalities using the calculation model presented in the article to indicate specific actions to improve air quality through a planned change in the heat generation structure. It should be clearly stated that the results obtained in individual models indicate the legitimacy of increasing the proportion of renewable energy sources used. In addition, building a sustainable energy mix on a local scale, at the same time as reducing the share of carbon, undoubtedly contributes to reducing emissions of pollutants into the environment.

The models presented in this paper show that, although there are already municipalities in Poland that prohibit the burning of fossil fuels (excluding natural gas), the most advantageous solution there is Model 7. The first results of these activities will be known after the end of the heating season, 2019/2020. Model 7 is characterised by the largest decrease in pollutant emissions compared to the basic model, which undoubtedly proves the need to take action to replace old boilers with new equipment and promoting solutions based on renewable energy sources.

Key Conclusions:

- The problem of low emissions in rural areas is primarily due to individual heat sources, which results from, among other reasons, a lack of infrastructure for district heating networks and gas networks.

- The classification of the individual heat sources analysed in this article on the basis of the emissions they produce, from the most to the least, is as follows: coal, biomass, heating oil, heat pumps.

- It should be noted that the heat pump in fact does not emit any pollution in the place of heat delivery, and the resulting emissions derive from the structure of electricity generation in Poland (majorly based on coal), which is necessarily used to drive the compressor and circulation pumps.

- Although heat pumps are a renewable energy solution to reduce heat emissions due to air pollution, it should be noted that from the socioeconomic aspect, the procurement of these devices is expensive for rural communities.

- The results obtained indicate that the structure of the energy sources used is the main problem. The effectiveness of the devices used does not significantly affect the results.

Author Contributions: Conceptualization: M.K., A.S. and B.T.; Formal analysis: A.S. and B.T.; Methodology: M.K.; Resources, M.K., A.S. and B.T.; Supervision: A.S. and B.T.; Visualization: M.K.; Writing-review \& editing, M.K., A.S. and B.T. All authors have read and agreed to the published version of the manuscript.

Funding: The research was funded under the AGH-UST statutory research grant No. 16.16.140.315/05.

Conflicts of Interest: The authors declare no conflict of interest

\section{References}

1. Kaczmarczyk, M. (Ed.) Niska Emisja: Od Przyczyn Występowania Do Sposobów Eliminacji; Geosystem Burek, Kotyza S. C.: Kraków, Poland, 2015.

2. Pałasz, J.W. Niska Emisja Ze Spalania Węgla I Metody Jej Ograniczania; Wydawnictwo Politechniki Śląskiej: Gliwice, Poland, 2016.

3. Tomaszewska, B.; Kasztelewicz, A.; Dendys, D.; Bujakowski, W.; Rahner, S.; Hartmann, H.; Weinreich, J. European educational concept in environmentalnature-and climate protection to safeguard a cross border sustainable development. E3S Web Conf. 2018, 66, 3005. [CrossRef]

4. Wang, X.; Klemes, J.J.; Dong, X.; Fan, W.; Xu, Z.; Wang, Y.; Varbanov, P.S. Air pollution terrain nexus: A review considering energy generation and consumption. Renew. Sustain. Energy Rev. 2019, 105, 71-85. [CrossRef]

5. Ligus, M.; Peternek, P. Determination of most suitable low-emission energy technologies development in Poland using integrated fuzzy AHP-TOPSIS method. Energy Procedia 2018, 153, 101-106. [CrossRef]

6. Dzikuć, M. Technical and economic aspects of low emission reduction in Poland. J. Clean. Prod. 2017, 22, 1107-1112. [CrossRef]

7. Ligus, M. Evaluation of economic, social and environmental effects of low-emission energy technologies in Poland-multi-criteria analysis. Energy Procedia 2017, 136, 163-168. [CrossRef] 
8. Gehrsitz, M. The effect of low emission zones in air pollution and infant health. J. Environ. Econ. Manag. 2017, 83, 121-144. [CrossRef]

9. Wolff, H.; Perry, L. Policy monitor trends in clean air legislation in Europe: Particulate matter and low emission zones. Rev. Environ. Econ. Policy 2010, 4, 293-308. [CrossRef]

10. Mayer, H. Air pollution in cities. Atmos. Environ. 1999, 33, 4029-4037. [CrossRef]

11. Cembrzyńska, J.; Krakowiak, E.; Brewczyński, P.Z. Zanieczyszczenie powietrza pyłem zawieszonym PM10 oraz PM2.5 w warunkach silnej antropopresji na przykładzie miasta Sosnowiec. Med. Środowiskowa-Environ. Med. 2012, 15, 31-38.

12. Block, M.L.; Elder, A.; Auten, R.L. The outdoor air pollution and brain health workshop. Neurotoxicology 2012, 33, 972-984. [CrossRef]

13. Young, J.D.; Anderson, N.M.; Naughton, H.T. Influence of Policy, Air Quality, and Local Attitudes toward Renewable Energy on the Adoption of Woody Biomass Heating Systems. Energies 2018, 11, 2873. [CrossRef]

14. Martins, F.; Felgueiras, C.; Smitkova, M.; Caetano, N. Analysis of Fossil Fuel Energy Consumption and Environmental Impacts in European Countries. Energies 2019, 12, 964. [CrossRef]

15. Troiano, S.; Vecchiato, D.; Marangon, F.; Tempesta, T.; Nassivera, F. Households' Preferences for a New 'Climate-Friendly' Heating System: Does Contribution to Reducing Greenhouse Gases Matter? Energies 2019, 12, 2632. [CrossRef]

16. Piwowar, A.; Dzikuć, M. Development of Renewable Energy Sources in the Context of Threats Resulting from Low-Altitude Emissions in Rural Areas in Poland: A Review. Energies 2019, 12, 3558. [CrossRef]

17. Moriarty, P.; Honnery, D. Energy Accounting for a Renewable Energy Future. Energies 2019, $12,4280$. [CrossRef]

18. Liu, F.; Zhang, K.; Zou, R. Robust LFC Strategy for Wind Integrated Time-Delay Power System Using EID Compensation. Energies 2019, 12, 3223. [CrossRef]

19. Höltl, A.; Macharis, C.; De Brucker, K. Pathways to Decarbonise the European Car Fleet: A Scenario Analysis; Using the Backcasting Approach. Energies 2017, 11, 20. [CrossRef]

20. Ju, L.; Tan, Z.; Li, H.; Tan, Q.; Yu, X.; Song, X. Multi-objective operation optimization and evaluation model for CCHP and renewable energy based hybrid energy system driven by distributed energy resources in China. Energy 2016, 111, 322-340. [CrossRef]

21. Xing, T.; Lin, H.; Tan, Z.; Ju, L. Coordinated Energy Management for Micro Energy Systems Considering Carbon Emissions Using Multi-Objective Optimization. Energies 2019, 12, 4414. [CrossRef]

22. Venghaus, S.; Märker, C.; Dieken, S.; Siekmann, F. Linking Environmental Policy Integration and the Water-Energy-Land-(Food-) Nexus: A Review of the European Union's Energy, Water, and Agricultural Policies. Energies 2019, 12, 4446. [CrossRef]

23. Schram, W.; Louwen, A.; Lampropoulos, I.; van Sark, W. Comparison of the Greenhouse Gas Emission Reduction Potential of Energy Communities. Energies 2019, 12, 4440. [CrossRef]

24. Specjał, A.; Lipczyńska, A.; Hurnik, M.; Król, M.; Palmowska, A.; Popiołek, Z. Case Study of Thermal Diagnostics of Single-Family House in Temperate Climate. Energies 2019, 12, 4549. [CrossRef]

25. Główny Urząd Statystyczny. Infrastruktura Komunalna W 2017 R; Główny Urząd Statystyczny: Warszawa, Poland, 2018.

26. Główny Urząd Statystyczny. Energia Ze Źródet Odnawialnych W 2018 R; Główny Urząd Statystyczny: Warszawa, Poland, 2019.

27. Główny Inspektorat Ochrony Środowiska; Państwowy Monitoring Środowiska-Inspekcja Ochrony Środowiska. Ocena Jakości Powietrza W Strefach W Polsce Za Rok; 2017; 2017; Główny Urząd Statystyczny: Warszawa, Poland, 2018.

28. European Environment Agency. Air Quality in Europe 2018 Report; European Environment Agency: Copenhagen, Denmark, 2018.

29. Sowiżdżał, A. Geothermal energy resources in Poland-Overview of the current state of knowledge. Renew. Sustain. Energy Rev. 2018, 82, 4020-4027. [CrossRef]

30. Sowiżdżał, A.; Chmielowska, A.; Tomaszewska, B.; Operacz, A.; Chowaniec, J. Could geothermal water and energy use improve living conditions? Environmental effects from Poland. Arch. Environ. Prot. 2019, 45, 109-118.

31. Schönfelder, T. (Ed.) Analiza Możliwości Ograniczania Niskiej Emisji Ze Szczególnym Uwzględnieniem Sektora Bytowo-Komunalnego; Ministerstwo Środowiska: Opole, Poland, 2011. 
32. Rahner, S.; Winter, I.; Hartmann, M.; Wittich, F.; Kasztelewicz, A.; Tomaszewska, B.; Pajak, L.; Dendys, M.; Operacz, A.; Mraz, M.; et al. Study on national activities and funding opportunities of furthering education programs for unemployed academics. E3S Web Conf. 2018, 66, 3004. [CrossRef]

33. Główny Urząd Nadzoru Budowlanego. Ruch Budowlany W 2018 R; Główny Urząd Nadzoru Budowlanego: Warszawa, Poland, 2019.

34. Dworkowska, A. Efektywność Energetyczna W Polsce. Przegląd 2013. Domy Jednorodzinne. Efektywność Energetyczna A Jakość Powietrza; Instytut Ekonomii Środowiska: Kraków, Poland, 2014.

35. Główny Urząd Statystyczny. Powierzchnia I Ludność W Przekroju Terytorialnym W 2019 R; Główny Urząd Statystyczny: Warszawa, Poland, 2019.

36. Główny Urząd Statystyczny. Zużycie Energii W Gospodarstwach Domowych W 2018 R; Główny Urząd Statystyczny: Warszawa, Poland, 2019.

37. Bielewicz, A.; Dziamara-Rzucidło, K.; Guła, A.; Koc, D.; Kojs, M.; Panek, A.; Rajkiewicz, A.; Sokulska, A.; Staniaszek, D.; Walencka, M.; et al. Strategia Modernizacji Budynków: Mapa Drogowa 2050; Instytut Ekonomii: Krakow, Poland, 2014.

38. Kaczmarczyk, M. Potential of existing and newly designed geothermal heating plants in limiting of low emissions in Poland. E3S Web Conf. 2018, 44, 62. [CrossRef]

39. Instytut Ochrony Środowiska-Państwowy Instytut Badawczy. Wskaźniki Emisji Zanieczyszczeń Ze Spalania Paliw. Kotty O Nominalnej Mocy Cieplnej Do 5 MW; Instytut Ochrony Środowiska-Państwowy Instytut Badawczy: Warszawa, Poland, 2015.

40. Schumacher, K.; Krones, F.; McKenna, R.; Schultmann, F. Public acceptance of renewable energies and energy autonomy: A comparative study in the French, German and Swiss Upper Rhine region. Energy Policy 2019, 126, 315-332. [CrossRef]

41. Poggi, F.; Firmino, A.; Amado, M. Planning renewable energy in rural areas: Impacts on occupation and land use. Energy 2018, 155, 630-640. [CrossRef]

42. Kostevsek, A.; Petek, J.; Cucek, L.; Kleme, J.J.; Varbanov, P.S. Locally Integrated Energy Sectors supported by renewable network management within municipalities. Appl. Therm. Eng. 2015, 89, 1014-1022. [CrossRef]

43. Benedek, J.; Tihamér-Tibor, S.; Bartók, B. Evaluation of renewable energy sources in peripheral areas and renewable energy-based rural development. Renew. Sustain. Energy Rev. 2018, 90, 516-535. [CrossRef]

44. Jenniches, S. Assessing the regional economic impacts of renewable energy sources-A literature review. Renew. Sustain. Energy Rev. 2018, 93, 35-51. [CrossRef]

45. Frank, A.G.; Gerstlberger, W.; Paslauski, C.A.; Visintainer-Lerman, L.; Ayala, N.F. The contribution of innovation policy criteria to the development of local renewable energy systems. Energy Policy 2018, 115, 353-365. [CrossRef]

(C) 2020 by the authors. Licensee MDPI, Basel, Switzerland. This article is an open access article distributed under the terms and conditions of the Creative Commons Attribution (CC BY) license (http://creativecommons.org/licenses/by/4.0/). 